\title{
Microstructural, mechanical and pozzolanic characteristics of metakaolin-based geopolymer
}

\author{
Yetunde Oyebolaji Abiodun ${ }^{1}$, Obanishola Muftau Sadiq², \\ Samson Oluropo Adeosun ${ }^{3}$ \\ ${ }^{1}$ University of Lagos, Department of Civil and Environmental Engineering; Nigeria; \\ e-mail: yabiodun@unilag.edu.ng (corresponding author); ORCID ID: 0000-0003-0233-631X \\ ${ }^{2}$ University of Lagos, Department of Civil and Environmental Engineering; Nigeria; e-mail: osadiq@unilag.edu.ng \\ ${ }^{3}$ University of Lagos, Department of Metallurgical and Materials Engineering; Nigeria; e-mail: sadeosun@unilag.edu.ng
}

(c) 2020 Author. This is an open access publication, which can be used, distributed and reproduced in any medium according to the Creative Commons CC-BY 4.0 License requiring that the original work has been properly cited.

Received: 5 February 2020; accepted: 26 April 2020; first published online: 21 May 2020

\begin{abstract}
The use of cement contributes to global $\mathrm{CO}_{2}$ emission and this leads to the depletion of ozone layer, causing global warming. The quest to reduce or eliminate this problem has resulted in the discovery of metakaolin-based geopolymer as an alternative to the use of cement in construction work. In this study, metakaolin obtained as a result of kaolin calcination from some deposits in Nigeria; Ogun (Imeko), Edo (Okpela), Ondo (Ifon) and Ekiti (Isan-Ekiti) were characterized and used to determine the compressive and flexural strength of metakaolin-based geopolymer concrete (Mk-GPC). Cubes of $150 \times 150 \times 150 \mathrm{~mm}$ were used for the compressive strength test and reinforced concrete beams of size $150 \times 250 \times 2160 \mathrm{~mm}$ were produced to test for flexural strength. A water-absorption test was also carried out on Mk-GPC and the effect of ball-milling was assessed on the strength properties. The results from the various tests showed that $800^{\circ} \mathrm{C}$ for 1 hour of calcination of kaolin gives best combination of performance properties due to the presence of amorphous silica in metakaolin. Mk-GPC gave higher compressive strength and at an early age than ordinary Portland cement (OPC) concrete. The water absorption capacities of Mk-GPC were higher than the control samples. In the flexural strength test, the reinforced beams failed in flexural-shear mode and the shear capacities at 28-, 56- and 90 -day curing age of the beams were between 0.656 and $0.938 \mathrm{MPa}$ for Mk-GPC beams and between 0.563 and $0.844 \mathrm{MPa}$ for the control beams. The moment capacities for the beams were between 19.25 and $33.25\left(\times 10^{3} \mathrm{kgm}^{2} / \mathrm{s}^{2}\right)$ for Mk-GPC beams and were between 22.75 and $28.0\left(\times 10^{3} \mathrm{kgm}^{2} / \mathrm{s}^{2}\right)$ for the control beams. The study has revealed that metakaolin-based geopolymer can serve as an alternative to cement for sustainable construction in the Nigerian construction industry.
\end{abstract}

Keywords: metakaolin, geopolymer concrete, compressive strength, flexural strength, reinforced concrete

\section{INTRODUCTION}

The production of Portland cement involves the decomposition of limestone (calcium carbonate) into lime $(\mathrm{CaO})$ and $\mathrm{CO}_{2}$ by the addition of heat. This decomposition process is accountable for the release of a large amount of $\mathrm{CO}_{2}$ into the atmosphere as a result of the chemical reaction involved.
The cement industry now accounts for about $8 \%$ of the annual global $\mathrm{CO}_{2}$ emissions (Boden et al. 2016, Andrew 2017). This is damaging to the environment, hence the search for alternative, more environmentally friendly cementitious materials such as geopolymers. According to Davidovits (2013), geopolymers are inorganic polymeric materials produced by the reaction of aluminosilicates 
with a highly concentrated alkaline solution. Metakaolin (Mk) is a complementary cementitious material that conforms to ASTM C618 (1994), Class $\mathrm{N}$ pozzolan specifications. $\mathrm{Mk}$ is unique in that it is not the by-product of an industrial process nor is it entirely natural; it is derived from a naturally occurring mineral and is manufactured specifically for cementing applications. Unlike by-product pozzolans, which can have variable composition, Mk is produced under carefully controlled conditions to refine its color, remove inert impurities, and tailor particle size (Brooks 2000, Jian-Tong 2002). As such, a much higher degree of purity and pozzolanic reactivity can be obtained. Mk has great promise as a complementary cementitious material, as it can improve many of the properties of concrete while also reducing cement consumption. The evolution of knowledge on geopolymer (GP), and more generally on alkali activated materials (AAM), tends to show that they could potentially offer an efficient alternative to ordinary Portland cement in particular applications. The term 'alkali activated materials' are applied to a class of solid materials synthesized by the reaction of an aluminosilicate powder with an alkaline solution (Alonso \& Palomo 2001). An alternative to alkaline activated geopolymers is the use of acid activators like phosphoric acid and organic carboxylic acids from plant extracts. The use of an acid medium also seems favorable, as some authors have demonstrated an increase of mechanical properties with acid-based geopolymers (Cao et al. 2005, Perera et al. 2008, Tchakouté \& Rüscher 2017).

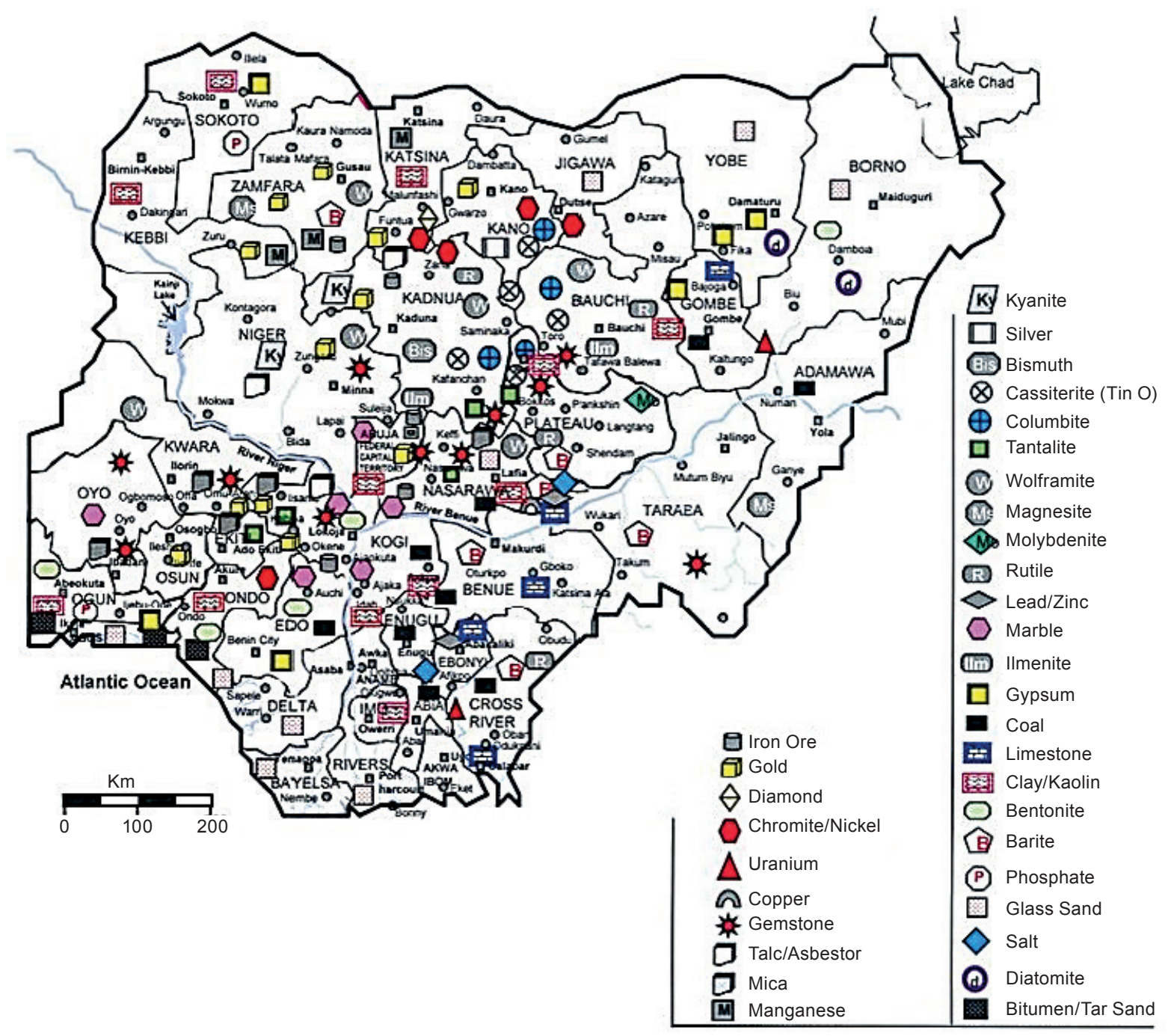

Fig. 1. Map showing the location of mineral resources in Nigeria 
The early benefits of geopolymers were in the areas of thermal resistant applications and fireproofing. In recent times, research on geopolymers has shifted its focus towards its use as a construction and building material. At present, geopolymers are swiftly evolving as a favorable unconventional binder material to ordinary Portland cement (OPC) due to their comparable mechanical properties (Aboulayt et al. 2017). However, despite these benefits, extensive commercial use of geopolymer concrete in the construction industry has encountered numerous practical, cost-effective and institutional barriers. Engineers are faced with reservations regarding properties, performance and lack of compliance to related codes of practice. In the area of specification of concrete for a construction project, engineers are familiar with specifying parameters such as minimum cementitious content, maximum water/cementitious material ratio and minimum 28-day compressive strength. Thus, the transition to alternative concretes would be facilitated by the use of similar and appropriately modified terminology (Marita et al. 2013). In Nigeria, there are vast deposits of kaolin in the South-West, South-East, South-South and North-West regions of the country (Fig. 1).

An estimate of the kaolin mineral deposit reserve in the country amounts to about 2 billion metric tons (Foraminifera Market Research, 2016). It has been reported that kaolinitic clay calcined to metakaolin from some parts of Nigeria can be used to partially replace cement and also has distinct characteristics (Abiodun et al. 2019). Hence, it is pertinent to determine the suitability of the metakaolin that could be obtained from Nigeria kaolin deposits as a geopolymer. This would help to efficiently and effectively tap into the mineral resources available in large amounts in Nigeria and to sustain rapid infrastructural development with affordable shelter and constructional materials. X-ray diffraction (XRD), Fourier transform infra-red spectroscopy (FTIR) and Differential thermal analysis (DTA) were employed to establish the amorphous nature of metakaolin and laboratory tests such as water absorption, compressive strength and flexural strength were carried out on Mk-GPC. The objectives are to determine the mineralogical characteristic of metakaolin from the study locations, with a compressive strength test of
Mk-GPC, a water absorption test on Mk-GPC, and the flexural strength (deflection and modes of failure) of reinforced Mk-GPC beams.

\section{MATERIALS AND METHODS}

\section{Materials}

Kaolin calcined to metakaolin at a temperature of $800^{\circ} \mathrm{C}$ for 60 minutes was sourced from four locations in Nigeria; Ogun (Imeko), Edo (Okpela), Ondo (Ifon) and Ekiti (Isan-Ekiti) states. This was based on the preliminary investigations as reported by Abiodun et al. (2019). $1.5 \mathrm{~kg}$ of the kaolin samples were calcined at different temperatures ranging from $500-1000^{\circ} \mathrm{C}$ (at $100^{\circ} \mathrm{C}$ interval) and heating times of $30,60,120$ and 180 minutes. It was reported that mass loss during calcination increases up to $800^{\circ} \mathrm{C}$ for 60 mins before it became negligible. Furthermore, the highest cumulative percentages of $\mathrm{SiO}_{2}, \mathrm{Al}_{2} \mathrm{O}_{3}$ and $\mathrm{Fe}_{2} \mathrm{O}_{3}$ were recorded at $800^{\circ} \mathrm{C}$ for 60 minutes in Ogun, Edo, Ekiti and Ondo metakaolin samples as 93.91, 90.44, 86.39 and $89.29 \%$ respectively. The cumulative percentage is in the range of $92.93 \%$ reported by Ambroise et al. (1994). Therefore, the four samples could be grouped as class N pozzolan (ASTM C618, 1994). The chemical composition of these kaolin samples are presented below (Tab. 1).

\section{Table 1}

Chemical composition of kaolin from the study locations (Abiodun et al. 2019)

\begin{tabular}{|l|c|c|c|c|}
\hline \multirow{2}{*}{$\begin{array}{c}\text { Compo- } \\
\text { sition }\end{array}$} & \multicolumn{4}{|c|}{ Content [\%] } \\
\cline { 2 - 5 } & Ogun & Edo & Ekiti & Ondo \\
\hline $\mathrm{SiO}_{2}$ & 48.50 & 47.82 & 42.54 & 39.87 \\
\hline $\mathrm{Al}_{2} \mathrm{O}_{3}$ & 32.75 & 31.65 & 29.07 & 30.72 \\
\hline $\mathrm{Fe}_{2} \mathrm{O}_{3}$ & 4.28 & 2.04 & 2.32 & 1.45 \\
\hline $\mathrm{CaO}$ & 1.08 & 1.02 & 1.09 & 0.96 \\
\hline $\mathrm{MgO}$ & 0.49 & 0.33 & 0.54 & 0.45 \\
\hline $\mathrm{Na}_{2} \mathrm{O}$ & 0.16 & 0.12 & - & 0.17 \\
\hline $\mathrm{K}_{2} \mathrm{O}$ & 1.48 & 1.54 & 1.03 & 1.26 \\
\hline $\mathrm{LOI}$ & 9.26 & 12.98 & 13.46 & 15.52 \\
\hline
\end{tabular}

\section{Methods}

\section{Mineralogical properties}

$\mathrm{X}$-ray diffraction (XRD) of the samples was made to check the authenticity of the metakaolin samples at National Geosciences Research Laboratories 
(NGRL) Kaduna, Nigeria using Empyrean XRD. The XRD equipment has a single crystal monochromatic (pyrolytic graphite) and a PIXcel 3D detector. The X-rays were generated by a cathode ray tube, filtered to produce monochromatic radiation, collimated to concentrate, and directed toward the sample. The interaction of the incident rays with the sample produced constructive interference (and a diffracted ray) when conditions satisfy Bragg's law $(n \lambda=2 d \sin \theta)$. Differential thermal analysis (DTA) was conducted at Obafemi Awolowo University, Nigeria using an INETZSCH DTA 404 PC. $5 \mathrm{mg}$ of each sample mass was subjected to heat using a DTA/TG $\mathrm{Al}_{2} \mathrm{O}_{3}$ crucible and heated from 20 to $1000^{\circ} \mathrm{C}$ at a constant rate of $10^{\circ} \mathrm{C} / \mathrm{min}$ in air. Fourier transform infra-red spectroscopy (FTIR) at Redeemer' University, Ede, Osun state, Nigeria using a Shimadzu Scientific spectrophotometer model.

\section{Pozzolanic reactivity of metakaolin}

To determine the pozzolanic reaction of metakaolin, $20 \mathrm{~g}$ of Mk was mixed with $100 \mathrm{ml}$ of saturated $\mathrm{Ca}(\mathrm{OH})_{2}$. The mixture was left for $1,2,3$ and 4 hours. The quantity of $\mathrm{Ca}(\mathrm{OH})_{2}$ reacted was determined at 25,75 and $100^{\circ} \mathrm{C}$.

\section{Ball milling and particle size analyses of metakaolin}

Using a planetary high-energy ball mill (Retsch PM 400), the metakaolin samples were ball milled for $1,2,3$ hours at rotation speeds of $\Omega=400 \mathrm{rpm}$ for the disc and $\omega=800 \mathrm{rpm}$ for the vials respectively. A particle size distribution test was carried out on samples which had been ball milled for 1 hour, while the hydrometer test was carried out on metakaolin samples which had been ball milled for 3 hours. For the hydrometer test, sodium hexametaphosphate solution was prepared by dissolving $33 \mathrm{~g}$ of sodium hexametaphosphate and $7 \mathrm{~g}$ of sodium carbonate in $1000 \mathrm{ml}$ of distilled water to make 1 liter of the solution. $50 \mathrm{~g}$ of each sample of metakaolin was weighed and mixed with $50 \mathrm{ml}$ of the prepared sodium hexametaphosphate solution to create segregation. The combined mixture was stirred in the electrically operated mixer for 20 minutes. After mixing, distilled water was added to the combined mixture to make $1000 \mathrm{ml}$ and later poured inside a glass cylinder. The top of the glass cylinder was covered with hand and inverted several times until the soil was in suspension. The cylinder was placed on a flat surface and the time was noted. Soil hydrometer was inserted immediately into the suspension and the first reading on the hydrometer was taken $40 \mathrm{~s}$ after the cylinder settled down. Further readings were taken at different interval for 24 hours. The procedure was repeated for the remaining samples.

\section{Mechanical properties of metakaolin-based geopolymer concrete}

Mk-GPCsampleswere cast using $150 \times 150 \times 150 \mathrm{~mm}$ molds to determine compressive strength. Eighteen cubes (18) were molded for the two ratios $(0.3$ and 0.4 ) of alkaline liquid to metakaolin. This means that three repeat samples were carried out per data point throughout this test. That is, at each curing day and for each ratio, three samples were cast, tested and the average result obtained. Compressive strength test was carried out at 7 , 28 and 90 days curing age in air- curing conditions at room temperature of $30 \pm 2^{\circ} \mathrm{C}$. The flexural strength test was also carried out on reinforced Mk-GPC beams and reinforced control beams. 0.4 ratio of alkaline liquid to metakaolin by mass was employed in casting the reinforced Mk-GPC beams. This ratio gave a better result than 0.3 when compared in the compressive strength test. The mix proportion is presented (Tab. 2). The moment capacity, shear capacity and modes of failure of reinforced Mk-GPC beams were determined in accordance with ASTM C78 (2016). $12 \mathrm{~mm}$ diameter bars of high yield steel were used as the main reinforcement while $10 \mathrm{~mm}$ diameter bars of high yield steel were used as links for the beams at $200 \mathrm{~mm}$ spacing $(\mathrm{c} / \mathrm{c})$ throughout. Eighteen (18) reinforced beams of size $150 \times 250 \times 2160 \mathrm{~mm}$ were designed and produced. Nine (9) of the beams were reinforced Mk-GPC and the remaining nine (9) were control beams. Three repeat samples per data point were carried out throughout this flexural strength test. The samples were aircured at room temperature for 28, 56 and 90 days. Test was carried out on the beam samples using four-point bending (two-points loading) system. 
Table 2

Mix proportion of reinforced Mk-GPC beams

\begin{tabular}{|l|c|c|c|c|c|c|c|c|}
\hline $\begin{array}{c}\text { Type of } \\
\text { concrete }\end{array}$ & $\begin{array}{c}\text { Ratio of } \\
\text { alkaline liquid } \\
\text { to Mk by mass }\end{array}$ & $\begin{array}{c}\text { Mass of } \\
\text { alkaline } \\
\text { liquid [Kg] }\end{array}$ & $\begin{array}{c}\text { NaOH } \\
\text { liquid [Kg] }\end{array}$ & $\begin{array}{c}\text { Sodium } \\
\text { silicate } \\
\text { liquid [L] }\end{array}$ & $\begin{array}{c}\text { Cement } \\
{[\mathrm{Kg}]}\end{array}$ & MK [Kg] & FA [Kg] & CA [Kg] \\
\hline A & 0.40 & 146.42 & 73.21 & 73.21 & - & 366.05 & 402.655 & 951.730 \\
\hline B & - & - & - & - & 372.26 & - & 409.486 & 967.876 \\
\hline
\end{tabular}

Explanations: A - metakaolin based geopolymer concrete, B - control, FA - fine aggregate (sharp sand), CA - coarse aggregate (granite).

Water absorption capacity test was conducted at the curing ages of 28 and 56 days on Mk-GPC and control samples in accordance with BS 1881-122 (1983). A total of 36 cube samples were tested for absorption capacity. Nine repeat samples were done per data point throughout this test. The number of repeat samples increased so as to determine efficiently the durability of Mk-GPC. On the day of testing, the samples were placed in the electric oven to dry at $105^{\circ} \mathrm{C}$ for 24 hours. They were then removed from the oven and allowed to cool at room temperature before determining the initial weight of each concrete sample, which was recorded as $\left(W_{1}\right)$. The final weight was determined after the concrete samples have been immersed in water for 24 hours. They were removed and dried with a piece of cloth; the re-weighed and recorded weight of each concrete sample as $W_{2}$. The equation used to compute the absorption capacity for the samples is given in Equation (1):

water absorption capacity $=\frac{W_{2}-W_{1}}{W_{2}} \times 100$

where:

$W_{1}$ - weight of the concrete sample after oven drying,

$W_{2}$ - weight of the saturated surface dry concrete sample.

\section{RESULTS AND DISCUSSION}

\section{Pozzolanic reactivity of metakaolin}

The graph shows the reactivity of metakaolin with $\mathrm{Ca}(\mathrm{OH})_{2}$ at different temperatures and reaction times (Fig. 2).
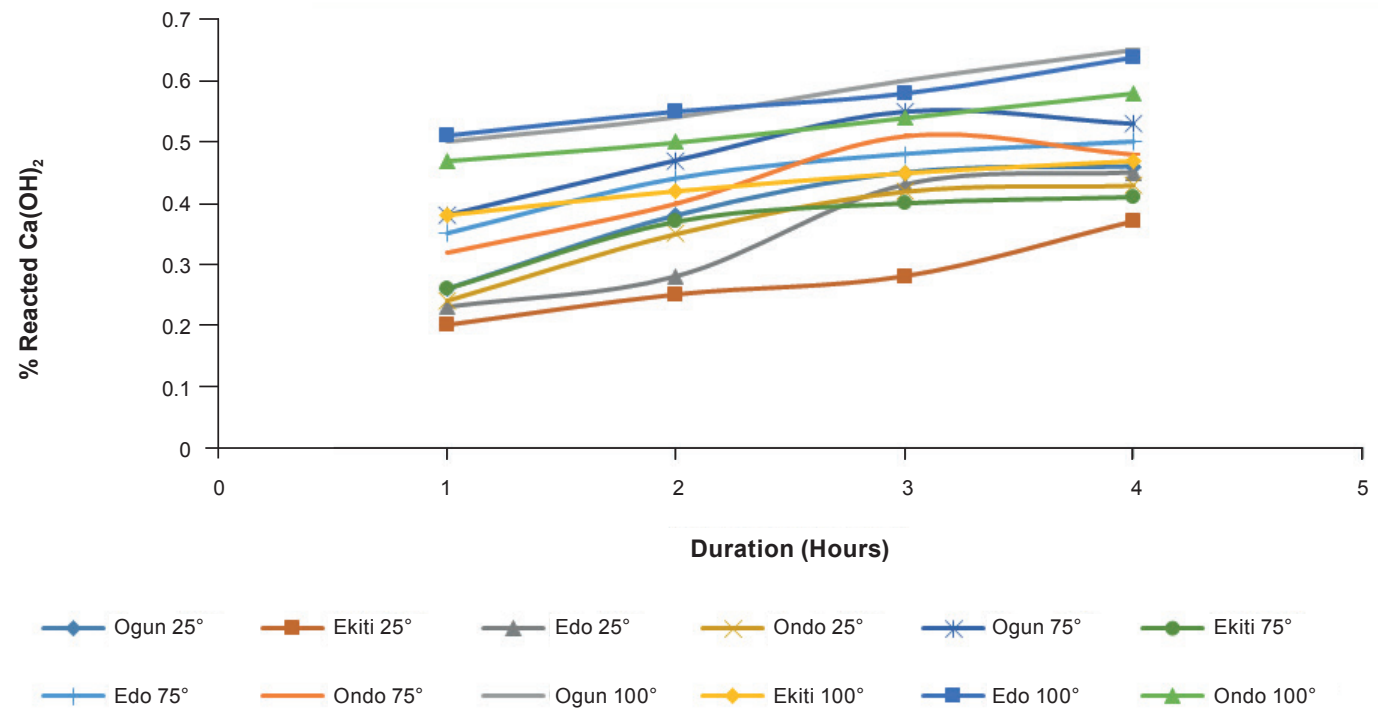

Fig. 2. Graph showing the pozzolanic reactivity of metakaolin with $\mathrm{Ca}(\mathrm{OH})_{2}$ 
It was observed that, as the duration and temperature increases, the percentage of $\mathrm{Ca}(\mathrm{OH})_{2}$ that reacted with metakaolin also increases. An increase in temperature from 25 to $100^{\circ} \mathrm{C}$ caused the percentage of $\mathrm{Ca}(\mathrm{OH})_{2}$ which reacted with metakaolin to increase from 0.45 to $0.68 \%$. This is an indication that metakaolin is able to consume or react with calcium hydroxide to produce the strength forming C-S-H gel. Also, the reaction between calcium hydroxide and metakaolin is influenced by temperatures. Higher reactivity occurred at the highest temperature of $100^{\circ} \mathrm{C}$. This shows that all chemical reactions are influenced by temperatures. From this test, the pozzolanic reactivity of metakaolin was established.

\section{Mineralogy of metakaolin}

\section{$X$-ray diffraction}

To confirm the disappearance of kaolinite peaks after thermal treatment, an XRD test was also carried out on calcined clay (metakaolin) and the XRD patterns are presented (Fig. 3). The kaolinite peaks disappeared during the calcining process, indicating the complete transformation of kaolinite to metakaolin. The XRD diffractograms of metakaolin samples were observed to be amorphous, as a result of the low intensity count, as well as the broad peaks.
All the prominent peaks at $2 \theta$ detected for the Ogun, Edo, Ekiti and Ondo kaolin samples have disappeared after calcination (Abiodun et al. 2019). This characteristic was expected due to the collapse of the structure by the $\mathrm{OH}$ group that is in between the plate like nature of kaolin, which led to a disorderly arrangement. The crystalline sizes of the metakaolin samples were calculated using Equation (2):

$D p=\frac{K \lambda}{B \cos \theta}$

where:

$D p$ - average crystalline size $[\mathrm{nm}]$,

$K$ - Scherrer constant; varies from 0.68-2.08,

$\lambda$ - X-ray wave length; $\mathrm{CuKa}=1.54178 \AA$,

$B$ - full width at half maximum (FWHM) of XRD peak,

$\theta$ - XRD peak position; one-half of $2 \theta$.

The crystalline sizes of the metakaolin samples for Ogun, Ondo, Edo and Ekiti are 48.26, 52.71, 56.05 and $93.49 \mathrm{~nm}$ respectively. The result shows that the Ogun metakaolin sample was the finest, while the Ekiti metakaolin sample was the coarser of the samples.

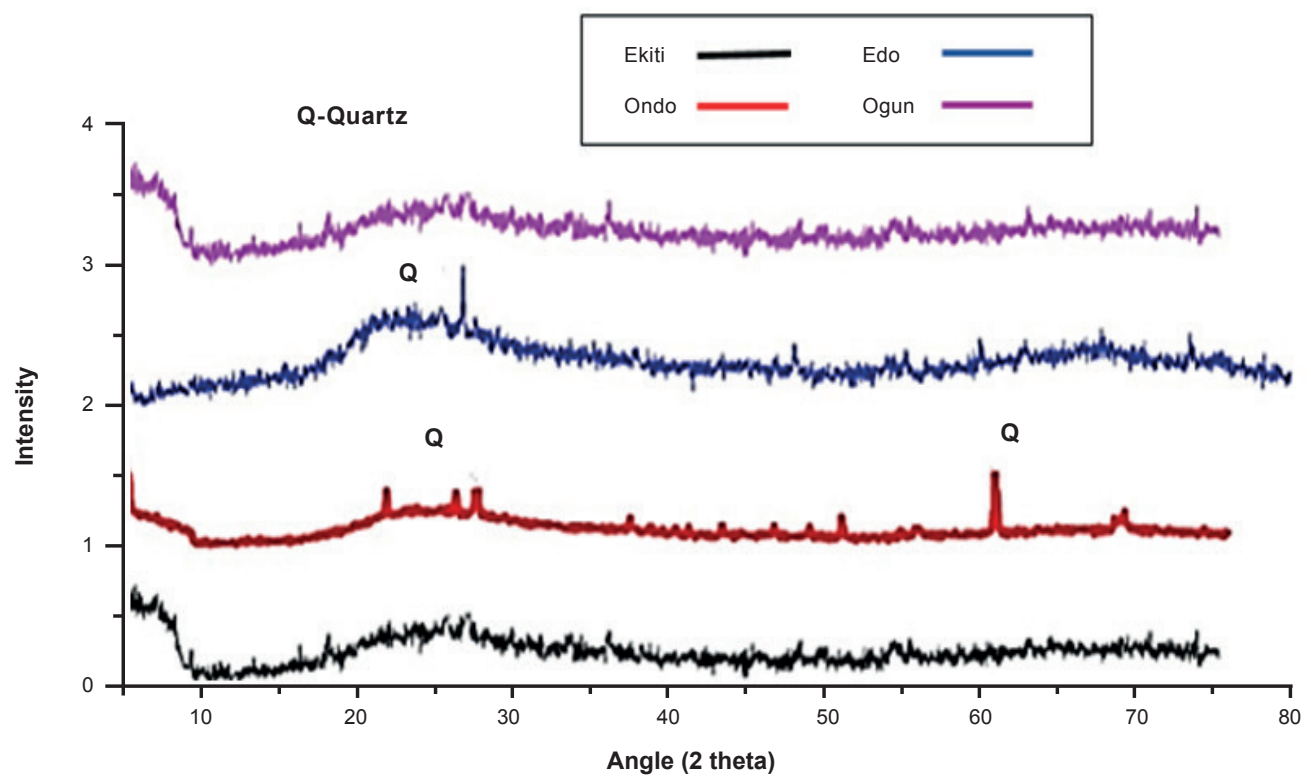

Fig. 3. XRD of metakaolin samples 


\section{Differential thermal analysis (DTA) of metakaolin}

As can be clearly observed, the kaolinite completely dehydroxylated to metakaolin (Fig. 4). Some phenomena that were observed (Fig. 5) which can be summarized in the following manner. At $100^{\circ} \mathrm{C}$, water absorbed in pores and on the surfaces were released.

Between 200 and $500^{\circ} \mathrm{C}$, an important phase where mass loss occurred was observed. This phase is also known as pre-dehydration phase. The endothermic reaction between 500 and $600^{\circ} \mathrm{C}$ showed transition from one phase to another. It signified the beginning of dehydration. From 600 to $850^{\circ} \mathrm{C}$ dehydroxylation of kaolinite to metakaolinite occurred. The conversion of metakaolin to spinel started at between 900 and $1000^{\circ} \mathrm{C}$, as indicated by an exothermic peak. At this point, recrystallization began and reactivity declined (Fig. 4). The DTA equipment used in this study recognized the downward reaction as exothermic as indicated.

\section{Fourier transform infra-red spectroscopy interpretation}

The Fourier transform infra-red spectroscopy (FTIR) method is much less prevalent for the quantifiable determination of clay and other minerals. Results of the FTIR of samples calcined at $800^{\circ} \mathrm{C} / 1$ hour are presented (Fig. 6).

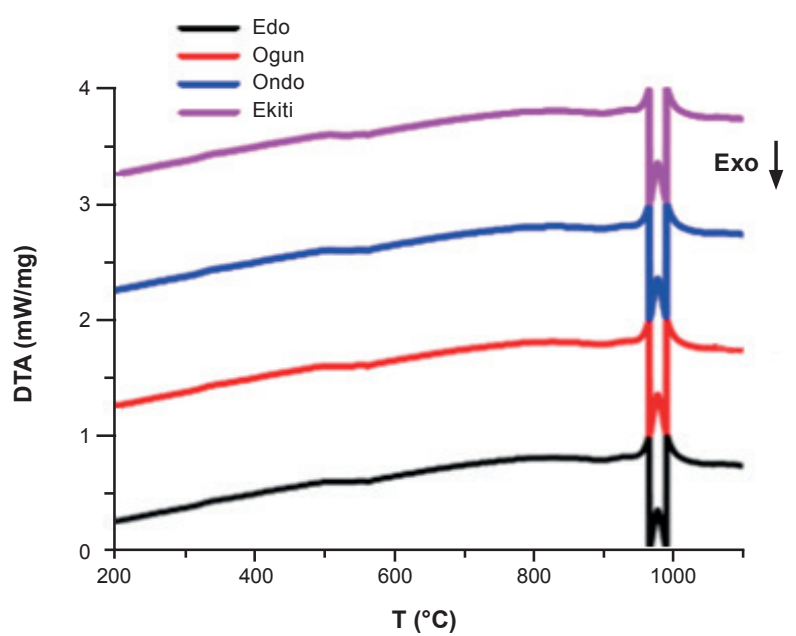

Fig. 4. DTA metakaolin samples

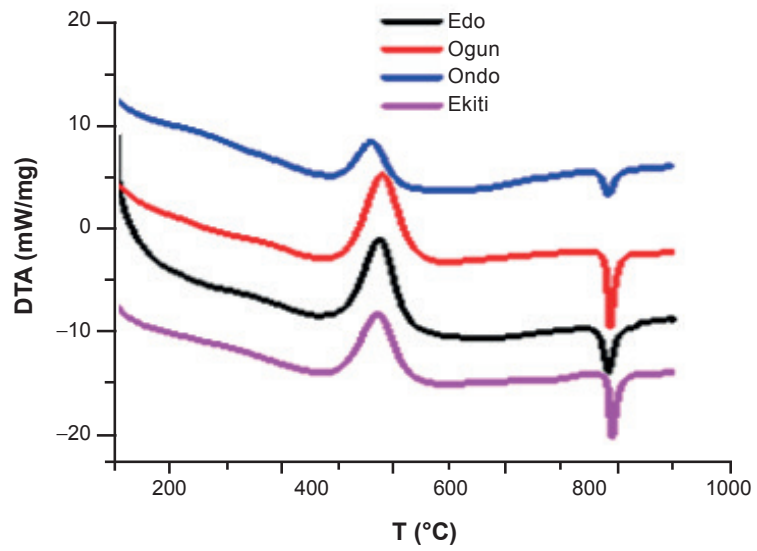

Fig. 5. DTA kaolin samples

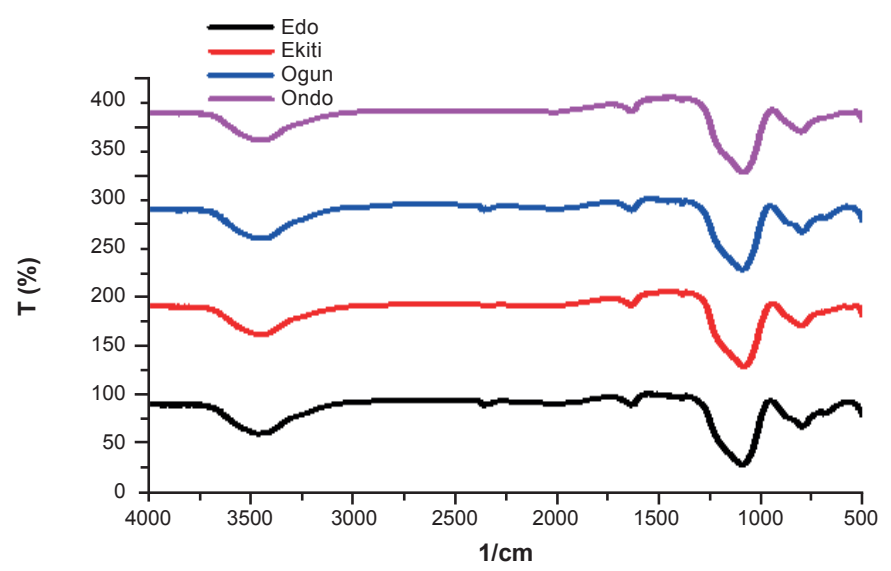

Fig. 6. FTIR for metakaolin samples 
Absence of the detectable Al-O-H bands between 914 and $912 \mathrm{~cm}^{-1}$, and the doublet between 3670 and $3500 \mathrm{~cm}^{-1}$, is evident. Absence of the band at $542.02,542.03,540.09$ and $531.40 \mathrm{~cm}^{-1}$ for Edo, Ogun, Ondo and Ekiti respectively as reported in Abiodun et al. (2019) and the appearance of a new band at $800 \mathrm{~cm}^{-1}$ can be related to the change from the octahedral coordination of $\mathrm{Al}^{3+}$ in kaolinite to tetrahedral coordination in metakaolinite (Fig. 6).

\section{Ball milling and particle size analysis}

Samples of metakaolin calcined at the best temperature and time of $800^{\circ} \mathrm{C} / 1$ hour and ball milled for 1 hour were analyzed with the result of the particle size distribution. Considering the metakaolin percentage passing through sieve $75 \mu \mathrm{m}$, Ogun, Ondo and Edo were observed to be finer than Ekiti (Fig. 7). The result of the percentage grain size distribution of metakaolin samples ball milled at 3 hours using hydrometer test is presented (Tab. 3). The determination of the grain size distribution in a clay deposit is of great significance in evaluating clays for industrial use. The grain size analysis of the samples shows that Ekiti metakaolin sample is coarsely grained while Ogun metakaolin sample is fine grained with $80 \%$ clay and $20 \%$ silt and no presence of gravel (Tab. 3). The result of the Ekiti sample shows a relatively high sand fraction while the Ogun one is mainly made up of a clay fraction, which is a typical characteristic of this sedimentary type.

\section{Table 3}

Grain size distribution [\%] using hydrometer test method

\begin{tabular}{|l|c|c|c|c|c|c|}
\hline $\begin{array}{c}\text { Loca- } \\
\text { tion }\end{array}$ & Clay & Silt & $\begin{array}{c}\text { Fine } \\
\text { sand }\end{array}$ & $\begin{array}{c}\text { Medium } \\
\text { sand }\end{array}$ & $\begin{array}{c}\text { Coarse } \\
\text { sand }\end{array}$ & Gravel \\
\hline Ogun & 80 & 20 & - & - & - & - \\
\hline Ondo & 78 & 18 & 4 & - & - & - \\
\hline Edo & 60 & 22 & 10 & 8 & - & - \\
\hline Ekiti & 51 & 14 & 20 & 10 & 5 & - \\
\hline
\end{tabular}

\section{Water absorption capacity test}

The Ogun metakaolin sample was used to carry out the water-absorption capacity test because it exhibited the best characterization properties. Mk-GPC specimens had high absorption capacity of 9.07 and $9.47 \%$ at 28 and 56 days curing age compared to OPC concrete specimens with 5.86 and $6.87 \%$ at 28 and 56 days respectively (Fig. 8). This could be attributed to the release of water contained in the Mk-GPC specimens when oven-dried. It agrees with the claims of Rangan (2010), that water is released during the formation of geopolymer (that is, during curing and further drying period of the matrix) leaving behind nano-pores. The implication of this is that it could make Mk-GPC samples more susceptible to attack.

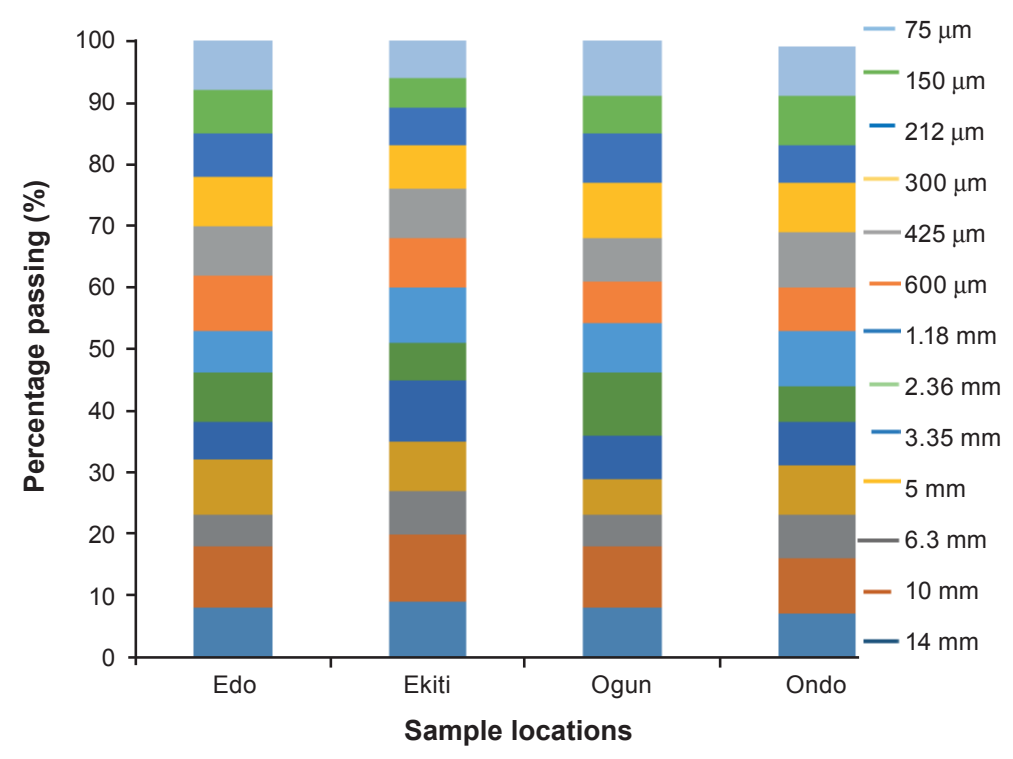

Fig. 7. Particle size distribution of study metakaolin samples ball milled for 1 hour 


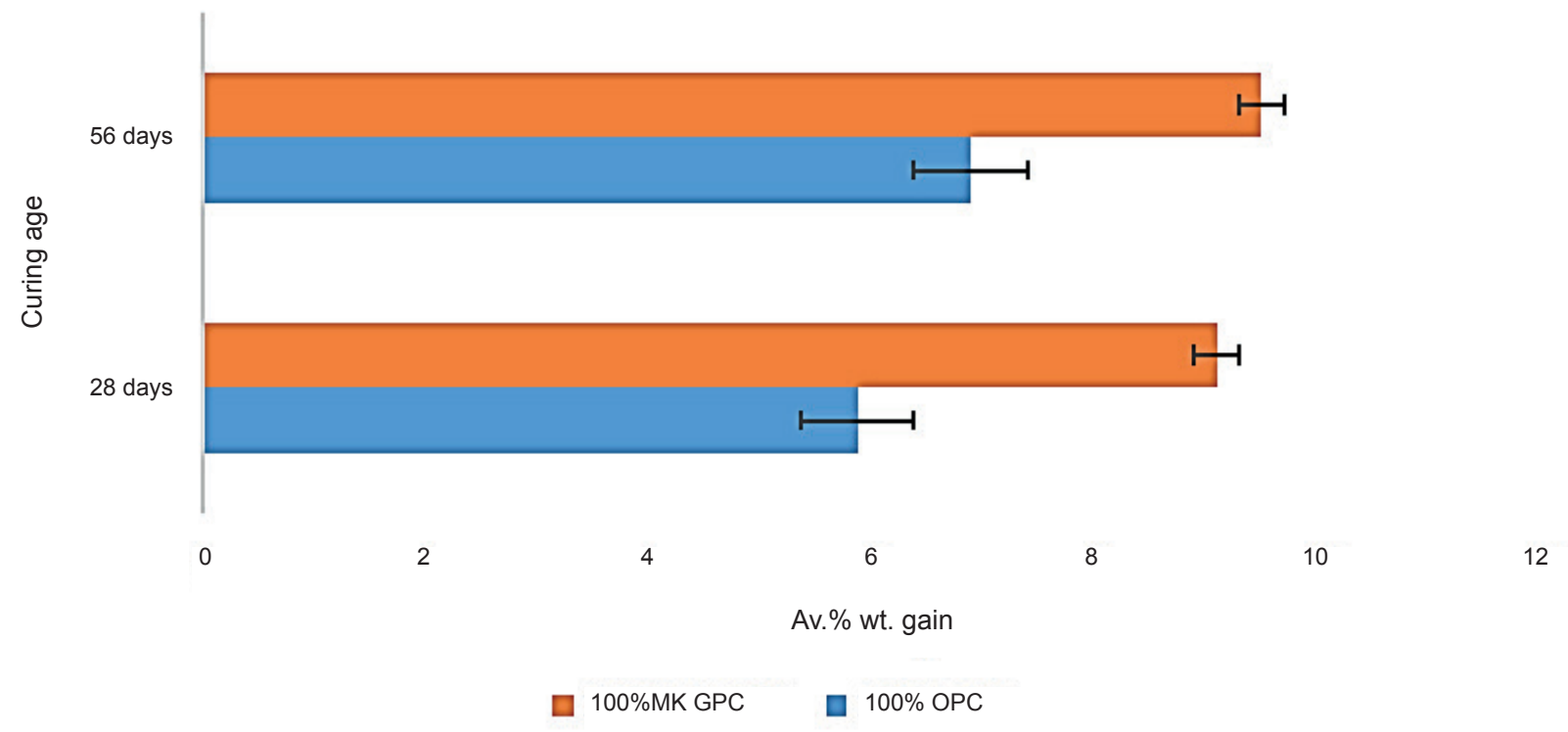

Fig. 8. Water absorption capacity of OPC concrete and Mk-GPC

\section{Effect of the particle size of metakaolin on the compressive strength of metakaolin based geopolymer concrete}

Compressive strength improved as the duration of milling increased (Tab. 4). This can be attributed to the increase in rate of metakaolin interaction in the matrix as a result of the greater surface area. This shows that the fineness of the particle size of metakaolin samples have an effect on the strength of Mk-GPC. The degree of the dehydroxylation of metakaolin is controlled by the calcination temperature of the kaolinitic clay. However, the milling duration affects the particle size and therefore the contact surface between metakaolin and alkaline solution.

Table 4

Average compressive strength $[\mathrm{MPa}]$ showing the effect of different particle sizes of metakaolin at 28 days

\begin{tabular}{|l|c|c|c|}
\hline \multirow{2}{*}{ Location } & \multicolumn{3}{|c|}{ Hours } \\
\cline { 2 - 4 } & $\mathbf{1}$ & $\mathbf{2}$ & $\mathbf{3}$ \\
\hline Ogun & 26.41 & 27.57 & 29.40 \\
\hline Ondo & 24.25 & 25.32 & 26.45 \\
\hline Edo & 25.21 & 25.61 & 26.48 \\
\hline Ekiti & 22.27 & 23.65 & 25.44 \\
\hline
\end{tabular}

\section{Compressive strength of} the metakaolin-based geopolymer concrete

The results showing a comparison of the compressive strength of Mk-GPC and OPC concrete is presented below (Fig. 9). It was also observed that a 0.4 alkaline liquid to metakaolin $(\mathrm{Mk})$ ratio gave a higher compressive strength than 0.3 at the same molarity of the $\mathrm{NaOH}$ solution because of the higher concentration. The result indicated that the alkaline liquid ratio controls the dissolution and polymerization of $\mathrm{Si}$ and $\mathrm{Al}$ in a geopolymer gel. Also, it was observed that curing at room temperature was beneficial to the geopolymer mix at all curing days. Compressive strength increased significantly at room-temperature when compared to being cured in water. This result is consistent with the literature (Xiao 2009) which showed that increasing curing temperature increases the kinetics of the geopolymerization process resulting in geopolymers with improved strength. Mk-GPC performed excellently well when compared to other categories of study concretes. Mk-GPC gained strength rapidly at an earlier stage than most OPC concretes. It was observed that at 28-days, compressive strength of Mk-GPC in this current study is 1.16 and 1.32 higher than that of OPC concrete at 1:1.5:3 and 1:2:4 mix ratios respectively as reported by Abiodun et al. (2019) 


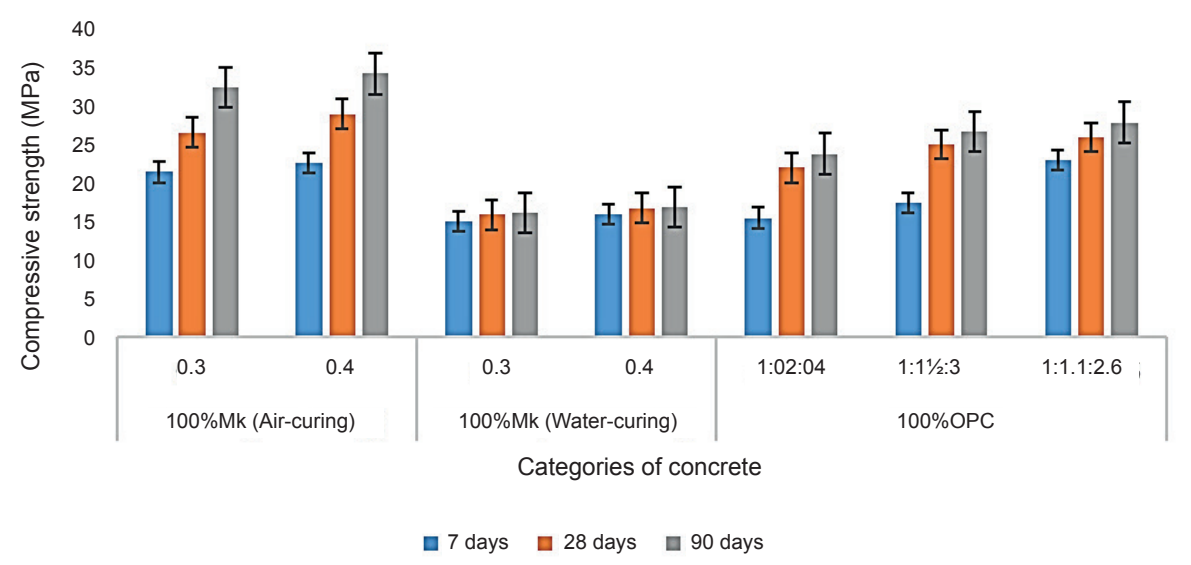

Fig. 9. Comparison of compressive strength of $M k-G P C$ and OPC concrete

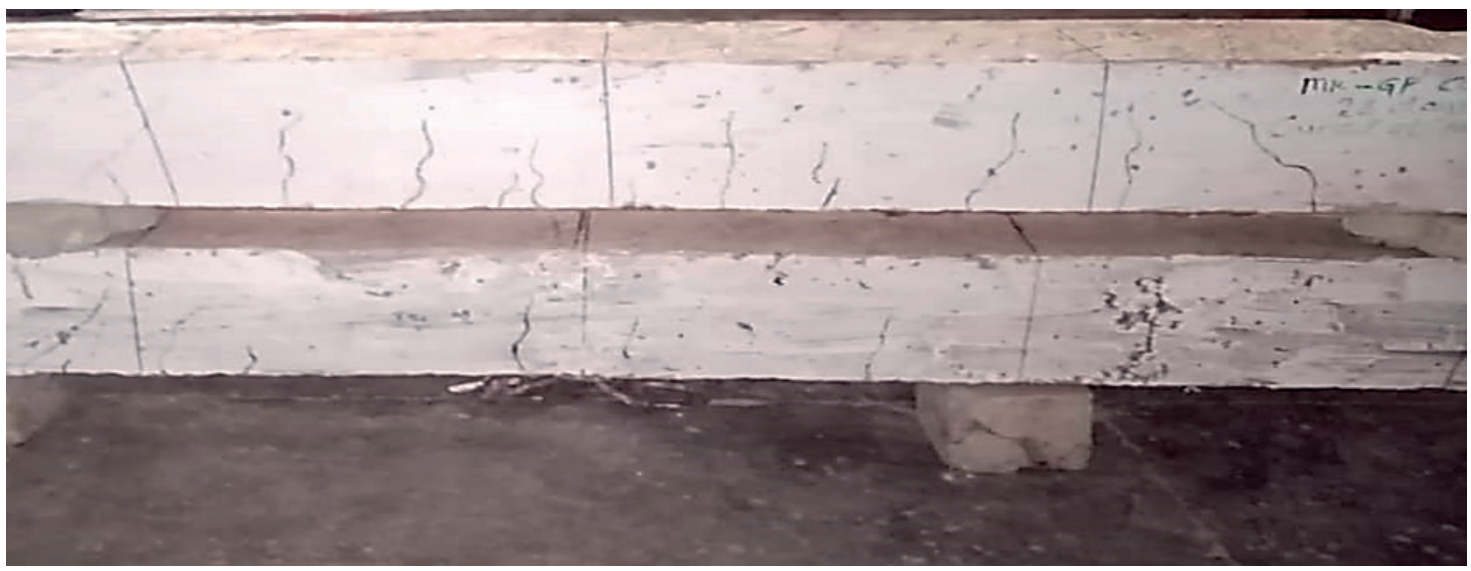

Fig. 10. Sample of reinforced $M k$-GPC beams

It was also observed that the critical period for geopolymer concrete is within the first week from mixing-casting process. The lack of a polymeric reaction within this period will result in reduced performance of the geopolymer concrete. As observed in conventional OPC concrete, strength development in geopolymer concrete became stable after 28 days. The higher strength development obtained via room-temperature curing was due to an increase in the polarization of $\mathrm{OH}^{-}$to break $\mathrm{Si}-\mathrm{O}$ and Al-O bonds on the metakaolin surface (North \& Swaddle 2000).

\section{Flexural behavior of metakaolin-based geopolymer concrete}

For all of the reinforced Mk-GPC beams (Fig. 10), the typical pattern of crack usually started at the supports and spread gradually. All the Mk-GPC beams experienced the same failure mode. Diagonal cracks appear from the middle third outwards. No web shear was observed in the beam specimens. According to Rashad (2015), this mode of failure is described as diagonal tension failure. This means that the beams still possess sufficient bending resistance at failure.

\section{Deflection and modes of failure of reinforced metakaolin-based geopolymer concrete beams}

The relationships of deflection to an applied load of reinforced Mk-GPC beams are shown (Fig. 11). As expected, the deflection of the beams increased with the applied load. The average deflection value of the specimens adequately reinforced to resist shear and flexural stresses before ductile failure occurred is $2.28 \mathrm{~mm}$. 
A

\begin{tabular}{|l|l|l|}
\hline Model & Allometric 1 & \\
\hline Equation & $\mathrm{v}=\mathrm{a}^{*} \mathrm{x}^{\wedge} \mathrm{b}$ & \\
\hline \multirow{3}{*}{ Adj. R-square } & Mk-GPC beam & 0.78728 \\
\cline { 2 - 3 } & Control beam & 0.9957 \\
\hline \multirow{2}{*}{ Mk-GPC beam } & $\mathrm{a}$ & 18.56712 \\
\cline { 2 - 3 } & $\mathrm{b}$ & 0.74935 \\
\hline \multirow{2}{*}{ Control beam } & $\mathrm{a}$ & 22.75288 \\
\cline { 2 - 3 } & $\mathrm{b}$ & 0.64921 \\
\hline
\end{tabular}

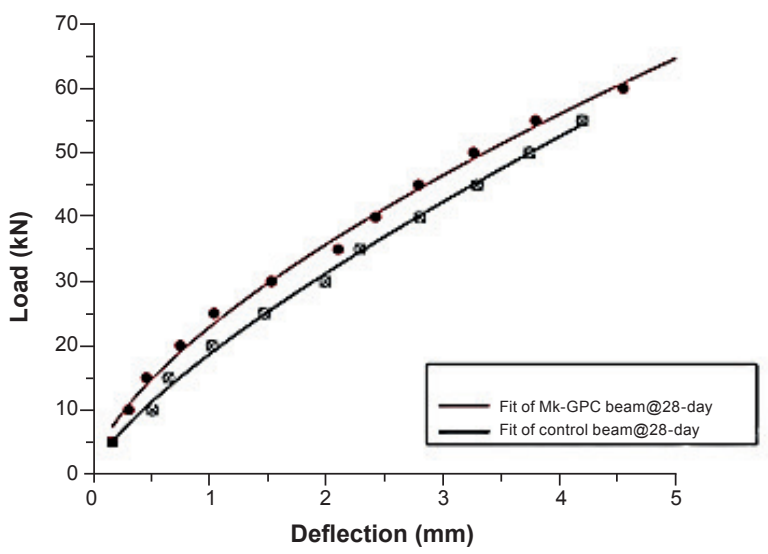

C

\begin{tabular}{|l|l|l|}
\hline Model & Allometric 1 & \\
\hline Equation & $\mathrm{v}=\mathrm{a}^{*} \mathrm{x}^{\wedge} \mathrm{b}$ & \\
\hline \multirow{3}{*}{ Adj. R-square } & Mk-GPC beam & 0.99297 \\
\cline { 2 - 3 } & Control beam & 0.99463 \\
\hline \multirow{3}{*}{ Mk-GPC beam } & $\mathrm{a}$ & 23.50716 \\
\cline { 2 - 3 } & $\mathrm{b}$ & 0.62201 \\
\hline \multirow{2}{*}{ Control beam } & $\mathrm{a}$ & 29.98969 \\
\cline { 2 - 3 } & $\mathrm{b}$ & 0.58809 \\
\hline
\end{tabular}

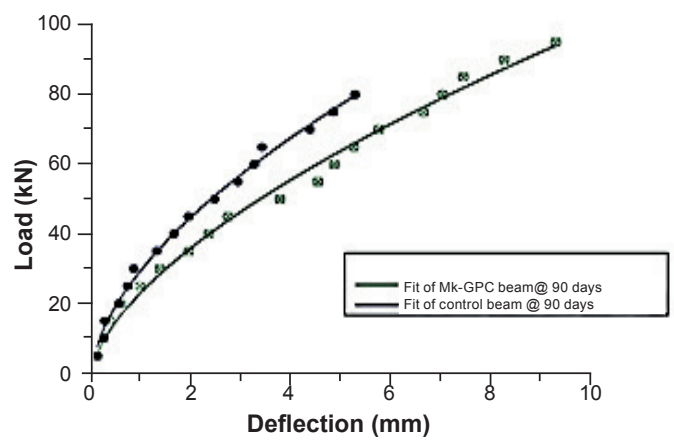

\section{$\mathrm{B}$}

\begin{tabular}{|l|l|l|}
\hline Model & Allometric 1 & \\
\hline Equation & $\mathrm{v}=\mathrm{a}^{*} \mathrm{x}^{\wedge} \mathrm{b}$ & \\
\hline \multirow{3}{*}{ Adj. R-square } & Mk-GPC beam & 0.99688 \\
\cline { 2 - 3 } & Control beam & 0.98798 \\
\hline \multirow{3}{*}{ Mk-GPC beam } & $\mathrm{a}$ & 25.05896 \\
\cline { 2 - 3 } & $\mathrm{b}$ & 0.67631 \\
\hline \multirow{2}{*}{ Control beam } & $\mathrm{a}$ & 26.19484 \\
\cline { 2 - 3 } & $\mathrm{b}$ & 0.66118 \\
\hline
\end{tabular}

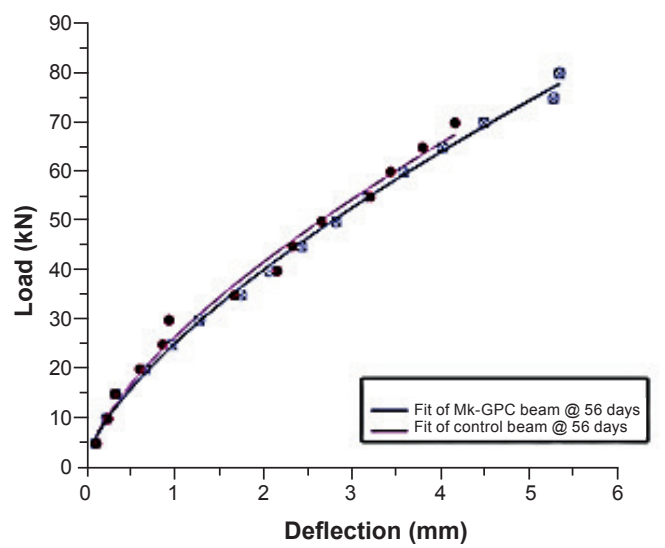

$\mathrm{D}$

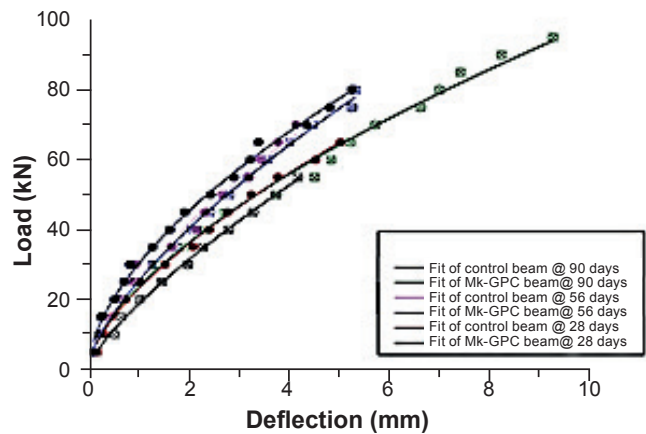

Fig. 11. Effect of increase in applied loads on the deflections of reinforced Mk-GPC beams: A)-C) load-deflection curves at 28, 56 and 90 days respectively; D) combined load-deflection curves at 28, 56 and 90 days 
The failure of the samples, which were all reinforced to resist both flexural and shear stresses, were preceded by the yielding of flexural reinforcement and accompanied by visible inclined hair-line cracks within the middle third of the beams. This indicates a flexural-shear failure mode, which is supported by Arthur el al. (2010), where if the applied stress in reinforced concrete beams exceeds the concrete-reinforcement bond stresses, shear cracks will propagate without restraints from the shear reinforcement.

\section{Moment and shear capacities of Mk-GPC beams at ultimate load using equations of equilibrium}

The moment and shear capacities of Mk-GPC beams at 28-, 56- and 90-day curing ages respectively are presented (Figs. 12, 13). The properties of Mk-GPC and the strength of the beams are high. Therefore, they can be used in construction works.

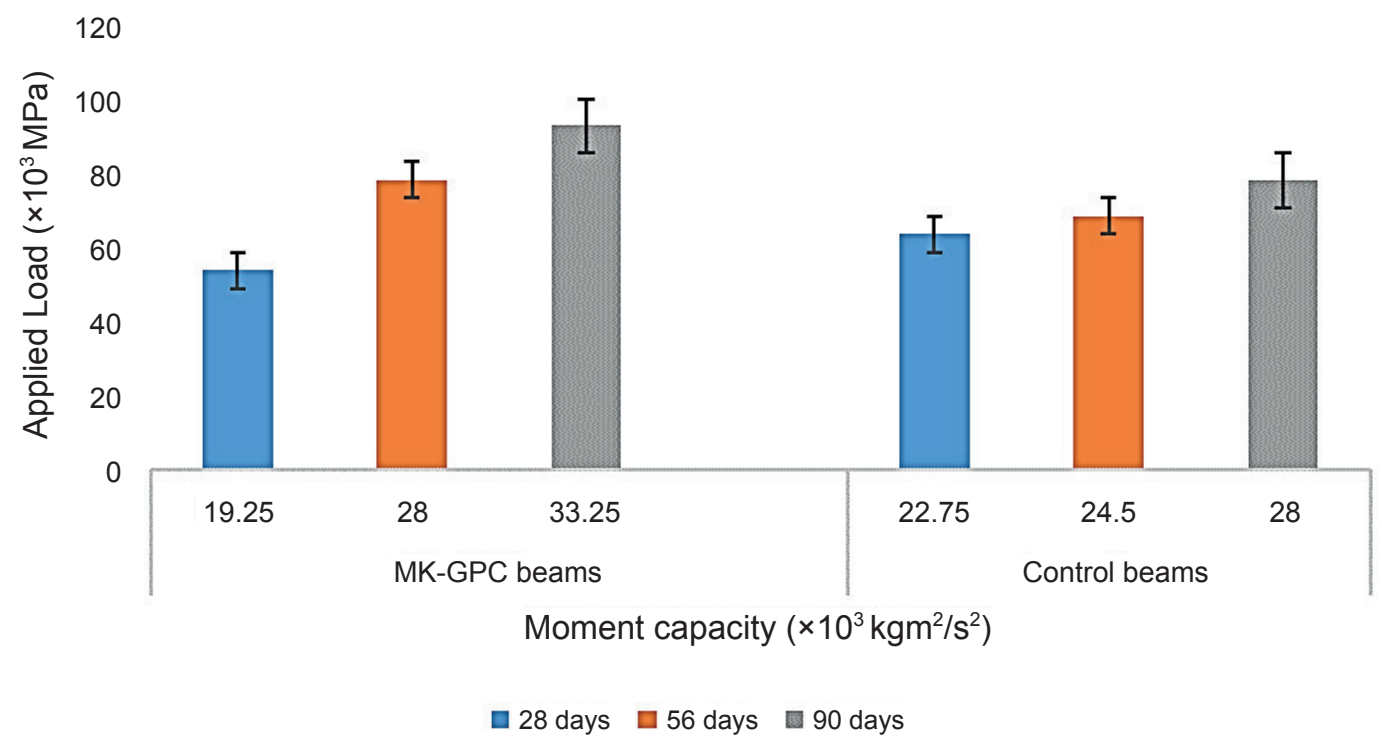

Fig. 12. Moment capacities of $M k$-GPC beams and control beams

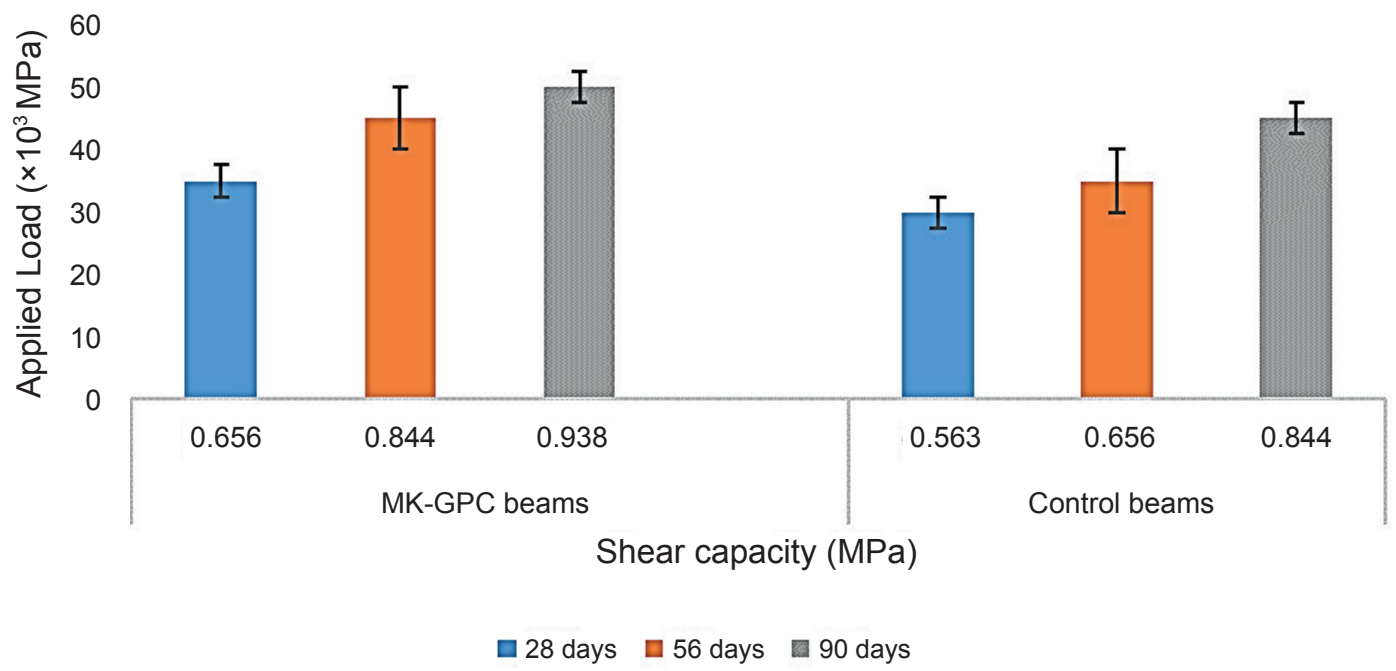

Fig. 13. Shear capacities of Mk-GPC beams and control beams 


\section{CONCLUSIONS}

Mk-GPC gave higher compressive strength and at an early age than OPC concrete. Therefore, it can be effectively used in the precast industries, so that tremendous amounts of production are possible in a short period and breakage during transportation will also be minimized. As the ratio of alkaline liquid to metakaolin increases, the compressive strength of Mk-GPC does so too. The higher the ratio of sodium silicate to sodium hydroxide by mass, the higher the compressive strength of Mk-GPC. The duration of ball-milling and particle size of metakaolin have significant effect on the strength properties of Mk-GPC. Reinforced Mk-GPC beams have high moment and shear capacities and these can be attributed to the high bond strength between metakaolin-concrete and reinforcement. Mk-GPC has higher water absorption capacities than control samples. The implication of this is that it could be susceptible to corrosion attack.

The authors duly appreciate the Central Research Committee, University of Lagos, Nigeria for the research grant CRC 2016/23 approved for this study.

\section{REFERENCES}

Abiodun Y.O., Sadiq O.M., Adeosun S.O. \& Oyekan G.L., 2019. Mineralogical properties of kaolin and metakaolin from selected areas in Nigeria and its application to concrete production. West Indian Journal of Engineering, 42(1), 57-64.

Aboulayt A., Riahi M., Ouazzani Touhami M., Hannache H., Gomina M. \& Moussa R., 2017. Properties of metakaolin based geopolymer incorporating calcium carbonate. Advanced Powder Technology, 28(9), 2393-2401.

Alonso S. \& Palomo A., 2001. Alkaline activation of metakaolin and calcium hydroxide mixtures: Influence of temperature, activator concentration, and solids ratio. Materials Letters, 47(1-2), 55-62.

Ambroise J., Maximilien S. \& Pera J., 1994. Properties of metakaolin blended cements. Advanced Cement Based Materials, 1, 4, 161-168, https://doi.org/10.1016/10657355(94)90007-8.

Andrew R.M., 2017. Global $\mathrm{CO}_{2}$ emissions from cement production. Earth System Science Data Discussions, August, 1-52.
ASTM C618, 1992. Specification for Chemical Composition of Pozzolans. ASTM International.

ASTM C78, 2016. Standard Test Method for Flexural Strength of Concrete (Using Simple Beam with Third-Point Loading). ASTM International.

Arthur H.N., David D. \& Charles W.D., 2010. Design of Concrete Structures. $14^{\text {th }}$ ed. McGraw-Hill, New York.

Boden T.A., Andres R.J. \& Marland G., 2016. Global, Regional, and National Fossil-Fuel $\mathrm{CO}_{2}$ Emissions. Carbon 25 Dioxide Information Analysis Center, Oak Ridge National Laboratory, U.S. Department of Energy, Oak Ridge, Tenn., U.S.A.

Brooks J.J., Johari M.A.M. \& Mazloom M., 2000. Effect of admixtures on the setting times of high-strength concrete. Cement and Concrete Composites, 22(1), 293-301.

BS 1881-122, 1983. Testing Fresh Concrete: Method for Determination of Water Absorption. British Standards Institution.

Cao D., Su D., Lu B. \& Yang Y., 2005. Synthesis and structure characterization of geopolymeric material based on metakaolinite and phosphoric acid. Journal Chinese Ceramic Society, 33, 1385-1389.

Davidovits J., 2013. Geopolymer Cement a Review. Geopolymer Science and Technics, Technical Paper, 21, Geopolymer Institute Library.

Foraminifera Market Research, 2016. Kaolin Deposits and Mining in Nigeria. The Opportunities, https://foramfera. com/2016/03/02/kaolin-deposits-and-mining-in-nigeria-the-opportunities/ [access: 2.03.2017].

Jian-Tong D., 2002. Effects of metakaolin and silica fume on properties of Concrete. ACI Material Journal, 13(6), $19-28$.

Marita L.B., Jay G.S., Kwesi S.C. \& Craig H., 2013. Overcoming barriers to implementation of geopolymer concrete. [in:] Concrete 2013: conference proceedings. Understanding concrete, Concrete Institute of Australia.

North M.R. \& Swaddle T.W., 2000. Kinetics of silicate exchange in alkaline aluminosilicates solutions. Inorganic Chemistry, 39, 2661-2665.

Perera D.S., Hanna J.V., Davis J., Blackford M.G., Latella B.A., Sasaki Y. \& Vance E.R., 2008. Relative strengths of phosphoric acid-reacted and alkali-reacted metakaolin materials. Journal of Materials Science, 43, 6562-6566.

Rangan V.B., 2010. Fly Ash-Based Geopolymer Concrete. [in:] Proceedings of the International Workshop on Geopolymer Cement and Concrete, Allied Publishers Private Limited, Mumbai, India, 68-106.

Rashad A.M., 2015. Metakaolin: Fresh properties and optimum content for mechanical strength in traditional cementitious materials - A comprehensive overview. Reviews on Advanced Materials Science, 40(1), 15-44.

Tchakouté H.K. \& Rüscher C., 2017. Mechanical and microstructural properties of metakaolin-based geopolymer cements from sodium waterglass and phosphoric acid solution as hardeners: A comparative study. Applied Clay Science, 140, 81-87.

Xiao Y., 2009. Geopolymerization process of alkali-metakaolinite characterized by isothermal calorimetry. Thermochimica Acta, 493, 49-54. 